Available online: https://journals.researchsynergypress.com/index.php/ijebce/

International Journal of Entrepreneurship, Business and Creative Economy (IJEBCE)

ISSN 2775-3085 (Online) | 2775-3107 (Print)

Volume 1 Number 2 (2021): 21-29

\title{
Analysis of the Advantages and Disadvantages of Using Social Media in Public Relations Practices to Convey Covid-19 Information in Gorontalo Province
}

\author{
Cahyadi Saputra Akasse ${ }^{1}$, Muh. Akbar' ${ }^{1}$ Arianto $^{1}$
}

${ }^{1}$ Communication Studies, Hasanuddin University, Indonesia

\begin{abstract}
Public Relations has an important role in educating and providing understanding to the public in the midst of the COVID-19 pandemic as it is now. In this case, Public Relations acts as an intermediary between the government and the community by conveying policies related to the government's efforts to prevent the spread of COVID-19. This study aims to analyze the advantages and disadvantages of PR strategies in delivering information on COVID-19 using social media, such as: websites, Facebook, Instagram, and YouTube. The method used in this research is descriptive qualitative with a case study approach. Then the withdrawal of research informants using purposive sampling technique, informants consist of people who are directly involved with the delivery of information on covid-19 by Public Relations, with qualitative data collection consisting of depth interviews, participant observation, and documentation. The results of the study show that there are several advantages, namely (1) wide reach and large number of followers, (2) fast information updates, and (3) presenting informative and educative content. The shortcoming in question is that the management of social media is not yet maximal, which is less interactive in responding to public comments through comments on social media. The limitation of this study is that researchers only focus on the PR strategy in delivering information about COVID-19 in Gorontalo Province through social media only and not at the level of other conventional media, namely through websites, Facebook, Instagram, and YouTube. The value and originality of this research is the delivery of information and efforts to prevent the spread of covid-19 which is conveyed through social media PR. The contribution of this research to future PR practices is a deeper implementation of the concept of digital PR, especially during a pandemic like now where everything is done online.
\end{abstract}

Keywords: Strategy; Public Relations; Information; Covid-19; Social Media

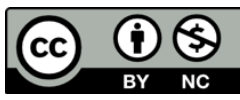

This is an open access article under the CC-BY-NC license.

\section{INTRODUCTION}

In practice, Public Relations acts as an intermediary between the organization (government) and the public. The main duties and functions of Public Relations are very crucial because they determine the course of good relations between the organization and the public. In a simple sense, PR or PR is a management function that forms a good relationship between the organization and the public which greatly affects the running of an organization (Cutlip et al., 2011). You could say that Public Relations is the mouthpiece of the government to the public, everything related to the image of the government is built from Public Relations itself.

The practice of Public Relations is very important to maintain the flow of information between the government and the public who become public from Public Relations itself, this function determines whether an organization runs well or not. Therefore, strategic steps are needed so that information between the government and the community can be maintained properly. By establishing a relationship between the community and the government, it can 
International Journal of Entrepreneurship, Business and Creative Economy (IJEBCE), Vol. 1 (2), 21-29

Analysis of the Advantages and Disadvantages of Using Social Media in Public Relations Practices to Convey Covid- 19 Information in Gorontalo Province

Cahyadi Saputra Akasse, Muh. Akbar, Arianto

improve the image of the government itself. Fake news that spreads in the community along with the development of communication technology makes public relations as a representation of the government itself more crucial. There needs to be a counter from Public Relations so that people are not easy to believe the fake news circulating.

In its specifications, Public Relations in government is an important liaison between government and society. In organizational and public information activities, the role of government public relations is greater than traditional public relations practices. Practitioners of public affairs today must master the art and skills of good communication and must have a thorough understanding of organizational culture, policies, practices, and constituents (Cutlip et al., 2011).

Public relations in the government has a great responsibility to be a liaison between the government and the community, it is not even an exaggeration to think that the fall and success of a government is determined by the effectiveness of the function of public relations At first the birth of Public Relations functioned mostly in the business world, but slowly the function of Public Relations began to be used, especially in democratic countries. The main function of Public Relations in government is as a government communicator, as well as a transmitter of government information to the public.

Public Relations has a close relationship with the public, how an organization under the auspices of Public Relations can get a good image from the public. The main form of activity for government public relations is as government relations or government relations. Government relations are intended to understand and influence public policies or regulations set by the government as a regulator (AndiPate, 2016).

Public relations activities in Indonesia in the implementation of communication technology were initially through Presidential Instruction No. 3 of 2003 concerning national policies and strategies for e- government development. This Presidential Instruction emphasizes the importance of communication technology in government activities, including public relations activities. The development of communication technology is part of the communication technology revolution, or more precisely referred to as the telecommunications revolution (Nurudin, 2017). In developed countries themselves, this activity is called Online Public Relations, which is an institution's communication activities with the public using the internet (Wiratmo et al., 2017).

With good use, social media can be the best solution in terms of information in the government and private sectors. This is further evidenced by the shift of government agencies to use social media, an indication that the development of communication technology brings changes to the communication culture. The presence of social media connects the community (users) through technological mechanisms (Nasrullah, 2017). One of the important components of the government's use of social media is its wide reach and unlimited territory (Kurniati et al., 2020).

The need for information in the midst of the pandemic COVID-19 as it is now is very crucial; there is a lot of information hoax circulating in the community and resulting in informational confusion which results in the emergence of concern in the community. The public's understanding of COVID-19 will be better if they are educated with clear and credible news. Therefore, credible information is needed in accordance with the conditions in the field so that the public is not confused by the confusion of this information. With this information, it is expected to be able to ward off information hoax that is often circulated in the community. Research on the use of communication technology in public relations practice was previously conducted by Irawan (2018) 
International Journal of Entrepreneurship, Business and Creative Economy (IJEBCE), Vol. 1 (2), 21-29

Analysis of the Advantages and Disadvantages of Using Social Media in Public Relations Practices to Convey Covid- 19 Information in Gorontalo Province

Cahyadi Saputra Akasse, Muh. Akbar, Arianto

regarding the use of websites to support activities cyber PR by the Tangerang city government. The use of website this is a government effort in terms of supporting public services.

As we already know, at the end of 2019 yesterday until now, the world is being hit by a pandemic of infectious diseases that afflict almost all regions of the world. This flu-like illness is called COVID-19 (coronavirus disease 19). In Indonesia itself, the first case of COVID-19 began in March 2020 through an Indonesian citizen who made contact with a Japanese citizen who was first exposed to COVID-19. The 31-year-old woman had entire Indonesian community, who at that time were still in shocked the shock by the news of COVID-19. The development ofcases dailyCovid-19 has increased significantly, this has resulted in the weakening of Indonesia's economic growth. In the second quarter of 2020, Indonesia's economic growth was at the level of $-5.32 \%$ (Wahdaniah \& Wahid, 2020). This weakening of economic growth has had a major impact on other sectors, this of course can be detrimental to the State.

In Gorontalo itself, the first positive case began in April 2020, which made Gorontalo two of the last provinces to be exposed to COVID-19. The explanation about the first case was delivered directly by the Governor of Gorontalo through the Gorontalo Province Public Relations social media account, it caused a very big reaction from the public. This became the beginning of the next positive cases in Gorontalo. The latest data is currently (28 March 2021) in Gorontalo there are 5103 total cases, reported from the official website of the Gorontalo Province Covid-19 Task Force, of the total cases, 4821 patients have recovered. This direct delivery from the Governor proved to be able to attract the public through live broadcasts, even after the press release from the Governor, the people shared the live broadcast on their respective social media.

The importance of the role of social media in this case is proven by the updates of the latest cases through the social media accounts of the Gorontalo Provincial Government, and of course these latest developments will be difficult when using conventional media such as newspapers which have to wait for a day to be loaded. The use of social media in daily activities has increased significantly, not only in the government sector but also in the education sector and other sectors. All teaching and learning activities are carried out via the internet. This trend has experienced a drastic increase compared to before theof onsetcovid (Hidayat et al., 2020). All students are required to familiarize themselves in the teaching and learning process with online methods through applications so that the teaching and learning process can still be carried out even though it must be done from their respective homes.

The Gorontalo government through the Public Relations and Protocol Bureau is aggressively updating information about COVID-19 on their social media. Often times, the social media Facebook from Humans broadcasts live broadcasts to convey information related to covid and also announcements regarding government regulations in the midst of a pandemic including the implementation of large-scale social restrictions (PSBB) for the Gorontalo area. Social media will be very useful if used properly in communication activities, and of course, the public must be given an understanding and education about the use of social media and get used to using social media in finding information. This research is a new thing, especially in PR practice, because it reveals what are the advantages and disadvantages of the PR strategy in conveying information in the midst of the pandemic COVID-19 as it is now. This is a new challenge in the practice of modern public relations as well as a separate reference in future public relations practices, especially during a pandemic like now. 
International Journal of Entrepreneurship, Business and Creative Economy (IJEBCE), Vol. 1 (2), 21-29

Analysis of the Advantages and Disadvantages of Using Social Media in Public Relations Practices to Convey Covid- 19 Information in Gorontalo Province

Cahyadi Saputra Akasse, Muh. Akbar, Arianto

Therefore, researchers are interested in conducting research to reveal the advantages and disadvantages of using social media in communication activities carried out by the Public Relations of Gorontalo Province in conveying information about COVID-19.

\section{LITERATURE REVIEW}

\section{Media sosial dan Cyber Public Relations}

By definition, social media is an internet platform that allows users to represent themselves or interact with each other in order to form a virtual social bond (Nasrullah, 2017). Digitalization is the main characteristic that separates social media from other forms of traditional media; social media lacks the drawbacks of printing and also traditional broadcasting models (McQuail, 2011). Any one of the meanings mentioned above compare social media to other types of digital media. Social media is the media, and most widely used means of information in today's society, for these characteristics (Ardha, 2014). This social media is one illustration in the rapid development of communication technologies in recent years.

Social media is used by the community today because of its easy access. Another reason for choosing social media is that it is cheap and easy to access, an example is the use of social media in PR Practices. The messages delivered by PR only need to be posted through a Facebook account, then the contents of these messages can be forwarded repeatedly by other followers to be conveyed to a wide audience.

Public relations have experienced several kinds of definitions due to advances in science and developments in information technology, in the end, public relations increasingly places communication as the center point of public relations studies and its implementation. Broadly speaking, PR is a management function that builds and maintains a good and beneficial relationship between an organization and the public that affects the success or failure of the organization (Cutlip et al., 2011).

The advancement of communication technology has resulted in significant improvements in public relations practitioners. The internet is increasingly expelling conventional mediadominated information channels. These changes also have a big impact on public communication activities, therefore PR in the future has a major task in responding to the development of this communication technology in exercise.

In the midst of the rapid development of communication technologies, the use of the web or cyber media is one step forward from PR practice. In a nutshell, cyber PR is a method of public affairs that utilize the information as its medium and is one of the applications of ICT (Information and Communications Technology) (Basit \& Rahmawati, 2018).

Public relations can now perform public relations activities at any time, without regard to time restraints, due to this cyber Public Relations. Leading up to the government's introduction and repressive behavior against the media, the public still found government public relations press releases to be just news that was not that significant. However, with the advancement in communication technology and the emergence of social media, public relations press releases are now the far news (Suprawoto, 2018).

The use of digital media or the internet to support public relations efforts is referred to as cyber public relations (Sanjaya et al., 2017). It is clear that cyber public relations emphasizes the use of the internet as a tool in public relations activities such as government-to-community relations or government- to-public information distribution. As a result of the internet's existence, public relations now plays a larger role than it has ever been. Some of the benefits of using cyber public relations include the ability to escape distance and time constraints, and also the ability to enable two-way contact (Irawan, 2018). 
International Journal of Entrepreneurship, Business and Creative Economy (IJEBCE), Vol. 1 (2), 21-29

Analysis of the Advantages and Disadvantages of Using Social Media in Public Relations Practices to

Convey Covid- 19 Information in Gorontalo Province

Cahyadi Saputra Akasse, Muh. Akbar, Arianto

\section{Situational Theory of The Publics}

Basically, the purpose of this STP theory is to identify the public based on their communication behavior. From this theory, it can provide more specific targets in public relations practice to reach the target public. The messages that are created are truly in accordance with the information needs of the public itself (Kriyantono, 2017). According to Grunig in (Cutlip et al., 2011) messages must be structured and adapted to provide the information needed by different publics, based on how passive or active their communication behavior is and what issues are important to them. Because it is situational, the problem or issue is dynamic, so the public is also dynamic. Problems come and go alternately and are only considered relevant by individuals who experience problematic situations related to organizational activities.

PR practitioners can use this theory to identify and categorize the public on the basis of perceptions, attitudes, and behavior of the public towards organizations both for practice and in critical situations (Kriyantono, 2017). That way the public can be grouped and the messages conveyed can be well received by the public itself. This public situation theory is very useful in public relations practice, especially in identifying the public and understanding their communication behavior.

\section{RESEARCH METHOD}

This research employed a qualitative descriptive approach including its tool. A qualitative paradigm can be defined as a research method that involves explaining and presenting in words or comprehensive reports obtained from natural sources of knowledge in order to explore personal or social problems (Mulyadi et al., 2019). This research will use a qualitative approach to examine the benefits and drawbacks of using social media to deliver knowledge. Covid-19 in the province of Gorontalo.

The study selects this type of qualitative study because he believes he can interpret phenomena holistically, such as the behavior of the research subject, and recognizes evidence in the field through perceptions about the issue to be studied. This is attributable to the fact that qualitative research places a focus on researchers' observations as a reference source. A case study is a type of research approach that has a definition, which is a concise overview or explanation of the aspects of a individual, group, organization (community), program, or social situation (Mulyana, 2013). Stake (1994) describes that some researchers emphasize study cases because they focus on what can be studied specifically in a single case after deductive approach (Mulyadi et al., 2019).

The informants were then extracted to use a purposive sampling technique, under which the informants in this study were chosen based on certain criteria based on the study's objectives (Sugiyono, 2020). The preferred informants are those who are directly related to the process of delivering information about Covid-19 to Gorontalo Province's Provincial Public Relations through social media. In- depth interviews, participant observation, and documentation are one of the qualitative data collection techniques used in this study. Data collection, data reduction, data presentation, or finally drawing conclusions are all part of the data analysis technique.

\section{FINDINGS AND DISCUSSION}

The use of social media by the Public Relations of Gorontalo Province is one of the major efforts and steps in the midst of the pandemic Covid-19 that has hit Indonesia, especially in Gorontalo. Given the conditions that are prone to conflicting information, Public Relations must be present in the community to deliver informative and educational news. That way the expected efforts such as community compliance with the health protocol can be achieved.

The use of social media is said to be quite successful if there is public awareness of the dangers of Covid and the implementation of the Health protocol has been going well in the community. After conducting research at the Public Relations Bureau of Gorontalo Province, 
International Journal of Entrepreneurship, Business and Creative Economy (IJEBCE), Vol. 1 (2), 21-29

Analysis of the Advantages and Disadvantages of Using Social Media in Public Relations Practices to Convey Covid- 19 Information in Gorontalo Province

Cahyadi Saputra Akasse, Muh. Akbar, Arianto

researchers got several statements regarding the advantages and disadvantages of the PR strategy of using social media in conveying information on Covid-19 in Gorontalo Province.

In its application, Gorontalo Province Public Relations has several social media accounts in an effort to convey information about Covid-19, including Facebook, Instagram, Website, and also Youtube. These four accounts have their own characteristics and advantages. For example, Facebook, which has a live broadcast feature, this can be used by Public Relations to hold press conferences to update the latest information about Covid-19.

Social media itself has a share feature that users can use to share on their respective social media, this is what happened in Gorontalo Province Public Relations social media, content about Covid-19 published on Gorontalo Province Public Relations social media is shared again by the public who become followers of social media and automatically can increase the reach of these social media even more.

If utilized properly, these advantages can have a positive impact on the government's efforts to prevent the spread of Covid-19 in Gorontalo, and the public can be educated about the dangers of Covid and always fully implement the Health protocol wherever and whenever. Based on the results of data collection in the form of interviews at Gorontalo Province Public Relations, there are several advantages, namely as follows:

\section{Advantages}

\section{Wide Reach and Large Followers}

Besides being easy to access, one of the advantages of using social media in delivering information is its wide reach. Through the sharing feature available on social media, it can create a wider reach, everyone who follows a PR social media account can share posts to their own social media accounts. With a large following, content published on social media PR can reach more people, especially every day social media users continue to grow.

With social media, people don't have to wait for newspapers in the morning or wait for prime time on television to access the latest information. Moreover, in the midst of a covid pandemic like now, people inevitably have to always access information at any time. The development of covid cases in the regions can be accessed more quickly through social media. Another thing is that social media is more interactive, because of the features provided on social media, such as the comment column. The public can immediately comment on any content posted on social media.

Even if viewed from the website visitor data site, it can be seen that the Gorontalo Province Public Relations website is visited by around a thousand people per day, and is a large number considering that the website is managed by the government, in the social media of Gorontalo Province Public Relations there is content that has been seen by 5 million people, this figure is greater than the population of Gorontalo itself. This means that it can be concluded that the content has reached from outside Gorontalo Province. The reach of social media is also determined by the number of followers.

The number of followers of Facebook PR is around 64 thousand. The number is quite large considering the population and the level of community literacy towards technology in the Gorontalo area which is not yet fast. The biggest increase in followers was when Covid entered Gorontalo, from March to April 2020, the increase in the number of followers per day was around a thousand more. Moreover, when doing live broadcasts, the increase can increase to two thousand people.

Social media if properly utilized can make the delivery of this information more effective and reach the wider community. The presence of social media makes people no longer wait for prime time for updated information. Whenever and wherever they only need to access social media 
International Journal of Entrepreneurship, Business and Creative Economy (IJEBCE), Vol. 1 (2), 21-29

Analysis of the Advantages and Disadvantages of Using Social Media in Public Relations Practices to Convey Covid- 19 Information in Gorontalo Province

Cahyadi Saputra Akasse, Muh. Akbar, Arianto

\section{Fast Update of Information}

In the midst of a pandemic like now, a media that can update information quickly is needed. This is because the public wants to always know the latest information about the development of Covid-19 and the government's efforts to prevent its spread.

One of the characteristics of social media is its access that can be anywhere and anytime as long as it is connected to the internet, so that to update the latest information about Covid-19 people no longer need to wait one day to buy newspapers, or wait for live broadcasts from television.

Another advantage is not only limited to its reach, with its characteristics, social media can be used for fast-paced information updates. This is very much needed in the midst of a pandemic like now; there is a need for media that can facilitate the government to convey information quickly and credibly so that things that are unwanted in society can be resolved with official news from the government.

From the results of data collection, researchers found that the use of social media can support community activities. Especially in terms of information about covid-19, the public can find out about the latest developments regarding covid as well as activities that are urged by the government such as implementing the Health protocol. People no longer need to wait for live broadcasts on television, on several occasions, Gorontalo Provincial Public Relations has conducted press releases through social media such as Facebook.

With social media, people can quickly access information anytime and anywhere by using the internet, the latest developments regarding Covid-19 in Gorontalo Province are immediately updated by Public Relations using their social media, namely, Facebook, Instagram, YouTube, and also through website. their official.

Crucial things, such as the implementation of PSBB in Gorontalo, can be quickly identified by the public, in this case, several provincial borders are closed for entry or exit. Therefore, this information must be made known to the public who will travel into or out of Gorontalo, with the existence of social media the government can convey this information right away so that it is known by the public so that it is anticipated

\section{Presenting Informative and Educative Content}

In the midst of a pandemic like now, informative and educational content is urgently needed. This of course can ward off unfounded information and prevent further worries arising in the community as a result of information hoax spreading. The public can also follow the government's appeal to maintain the Health protocol because the delivery of information through social media is delivered through educational content that can educate the public.

Apart from the two advantages above, the use of social media in delivering information about Covid- 19 is considered to be able to present informative and educational content. This is because any information conveyed by this PR first goes through a good process and planning. Also, because the information comes directly from the government, the public does not need to worry about the authenticity of the news conveyed by PR through social media.

This informative and educational content can make the public more obedient to the government's appeal, and the goal of the government to prevent the spread of covid-19 can be maximized. This informative and educational content can also anticipate false information that is often circulating in the public regarding Covid-19, and the confusion over information can be minimized. 
International Journal of Entrepreneurship, Business and Creative Economy (IJEBCE), Vol. 1 (2), 21-29

Analysis of the Advantages and Disadvantages of Using Social Media in Public Relations Practices to Convey Covid- 19 Information in Gorontalo Province

Cahyadi Saputra Akasse, Muh. Akbar, Arianto

\section{Deficiency}

The drawbacks obtained from the findings of the researchers do not cover the advantages previously described. There are very few shortcomings that researchers can get from this study regarding the use of social media in the PR campaign of Gorontalo Province; this is an indication that social media can provide a significant change in PR activities.

Based on the results of the above research, it shows that currently Gorontalo Province Public Relations has not been maximized in terms of interaction with the community through social media. The content published on the Gorontalo Province Public Relations social media is only for information, people who provide comments are not immediately replied to by the Gorontalo Province Public Relations social media operator.

It would be very good in the future if Gorontalo Provincial Public Relations is not only limited to providing information, but can respond to responses from the community through social media. That way, two-way communication can be created, and doesn't demand the possibility to attract more attention from the public.

This deficiency can be overcome if Gorontalo Provincial Public Relations improves its social media management. That way, the public is increasingly interested in providing their response, and the Government can directly assess the community's responses in improving services, especially in information services.

Information from the government through PR about Covid can be well received by the public if there is a direct response from the government, for example through social media. One of them is when the Large- Scale Social Restrictions (PSBB) are implemented, people who want to find out more cancomment on their PR social media accounts.

\section{CONCLUSION}

The PR strategy uses social media to convey information about Covid-19 there are several advantages and disadvantages. This can be used as material for future evaluation of Gorontalo Province Public Relations activities. The advantages referred to are (1) wide reach and large followers, then (2) fast updating of information, and finally (3) presenting informative and educational content. The shortcomings found were the inadequate management of social media which was less interactive in responding to responses from the public through the comment column on social media. It would be better in the future if the management of this social media can be improved so that it will attract more interest from the public to access social media for PR.

\section{REFERENCES}

AndiPate, A. A. (2016). Paradigma Baru Public Relations - Teori, Strategi, dan Riset. Pustaka Indonesia.

Ardha, B. (2014). Social Media Sebagai Media Kampanye Partai Politik 2014 di Indonesia. Jurnal Visi Komunikasi, 13(1), 16. https://doi.org/https://dx.doi.org/10.22441/jvk.v13i1.383

Basit, A., \& Rahmawati, T. H. (2018). Cyber Public Relations (E-PR) dalam Brand Image Wardah Kosmetik dengan Pedekatan Mixed Method. Nyimak (Journal of Communication), 1(2). https://doi.org/10.31000/nyimak.v1i2.483

Cutlip, S. M., Center, A. H., \& Broom, G. M. (2011). Effective Public Relations (9 ed.). Kencana Prenada Media Group.

Hidayat, D., Gustini, L. K., \& Dias, M. P. (2020). Digital Media Relations Pendekatan Public Relations dalam Menyosialisasikan Social Distancing di Kota Bandung. Jurnal Ilmu Komunikasi, 18(3), 257. https://doi.org/10.31315/jik.v18i3.3575

Irawan, E. P. (2018). Pemanfaatan Website Pada Aktivitas Cyber PR dalam Mendukung eGovernment di Pemerintah Kota Tangerang Selatan. JURNAL IPTEKKOM : Jurnal Ilmu $\begin{array}{lllll}\text { Pengetahuan \& Teknologi Informasi, } & 163 .\end{array}$ 
International Journal of Entrepreneurship, Business and Creative Economy (IJEBCE), Vol. 1 (2), 21-29

Analysis of the Advantages and Disadvantages of Using Social Media in Public Relations Practices to Convey Covid- 19 Information in Gorontalo Province

Cahyadi Saputra Akasse, Muh. Akbar , Arianto

https://doi.org/10.33164/iptekkom.19.2.2017.163-177

Kriyantono, R. (2017). Teori-teori Public Relations Perspektif Barat \& Lokal: Aplikasi Penelitian dan

Praktik. Kencana Prenada Media Group.

Kurniati, Munir, M., Hamidah, L., \& Rizky, A. S. (2020). Monitoring dan evaluasi humas pemerintah dalam penggunaan media sosial untuk memerangi hoaks. Jurnal Manajemen Komunikasi, 05(01). https://doi.org/https://doi.org/10.24198/jmk.v5i1.27616

McQuail, D. (2011). Teori Komunikasi Massa. Salemba Humanika.

Mulyadi, S., Basuki, A. M. H., \& Prabowo, H. (2019). Metode Penelitian Kualitatif dan Mixed Method. Rajagrafindo Persada.

Mulyana, D. (2013). Metode Penelitian Kualitatif. Remaja Rosdakarya.

Nasrullah, R. (2017). Media Sosial: Perspektif Komunikasi, Budaya, dan Sosioteknologi (N. S. Nurbaya (ed.)). Simbiosa Rekatama Media.

Nurudin. (2017). Perkembangan Teknologi Komunikasi (1 ed.). PT. Rajagrafindo Persada.

Sanjaya, A., Irwansyah, \& Alunaza, H. (2017). Pemeliharaan Hubungan dan Komunikasi Organisasi via Media Siber. Jurnal Ilmu Komunikasi, 14(02). https://doi.org/https://doi.org/10.24002/jik.v14i2.886

Sugiyono. (2020). Metode Penelitian Kualitatif. Alfabeta.

Suprawoto. (2018). Goverment Public Relations. Prenadamedia Group.

Wahdaniah, I., \& Wahid, U. (2020). Strategi Manajemen Krisis Public Relations TNI Angkatan Laut dalam Menghadapi Pandemi Covid-19. Warta ISKI, 3(02), 160-167. https://doi.org/10.25008/wartaiski.v3i02.72

Wiratmo, L. B., Irfan, N., \& Kuwatono, K. (2017). Website Pemerintah Daerah sebagai Sarana Online Public Relations. Jurnal Aspikom, 03(02), 14.

https://jurnalaspikom.org/index.php/aspikom/article/view/139 